\title{
Synthesis of Cannabidiols via Alkenylation of Cyclohexenyl Acetate
}

\author{
Akira Takeuchi, Yong-Gang Wang, and Yuichi Kobayashi* \\ Department of Biomolecular Engineering, Tokyo Institute of Technology \\ 4259 Nagatsuta-cho, Midori-ku, Yokohama 226-8501, Japan
}

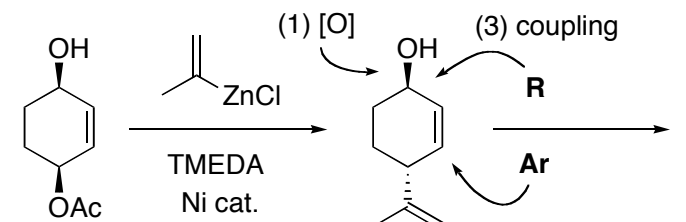

(2) 1,4-addition

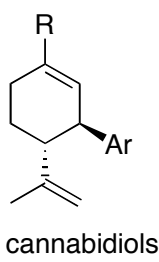

$\mathrm{R}=\mathrm{Me}, \mathrm{CH}_{2} \mathrm{OH}$ 


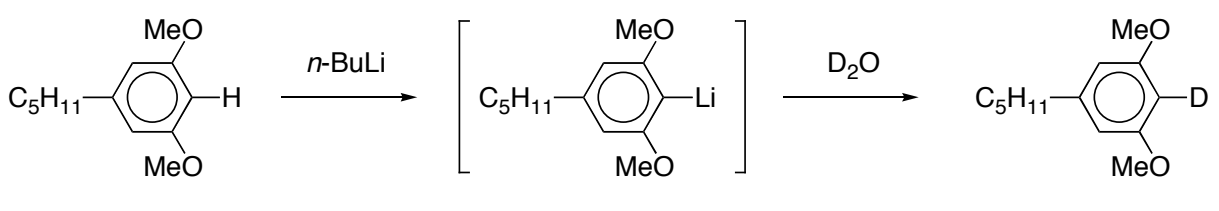

12

Table S1. Lithiation of dimethyl ether of olivetol ${ }^{\mathrm{a}}$

\begin{tabular}{cllllll}
\hline & & & & & time, & incorporation \\
entry & $\mathrm{RLi}($ equiv) & solvent & additive $^{\mathrm{b}}$ & temp. & $\mathrm{h}$ & $\mathrm{of}, \%$ \\
\hline 1 & $n$-BuLi (1.0) & $\mathrm{Et}_{2} \mathrm{O}$ & - & room temp. & 2 & 36 \\
2 & sec-BuLi (1.0) & $\mathrm{Et}_{2} \mathrm{O}$ & - & room temp. & 2 & 44 \\
3 & $t$-BuLi (1.0) & $\mathrm{Et}_{2} \mathrm{O}$ & - & $-78 \sim-50{ }^{\circ} \mathrm{C}$ & 2 & 14 \\
4 & $n$-BuLi (1.0) & $\mathrm{THF}$ & - & room temp. & 2 & 36 \\
5 & sec-BuLi (1.0) & $\mathrm{THF}$ & - & room temp. & 2 & 43 \\
6 & $n$-BuLi (1.2) & $\mathrm{Et}_{2} \mathrm{O}$ & - & room temp. & 2 & $66-73$ \\
7 & $n$-BuLi (1.2) & $\mathrm{Et}_{2} \mathrm{O}$ & $\left(\mathrm{ClCH}_{2}\right)_{2}$ & room temp. & 2 & 63 \\
8 & $n$-BuLi (1.2) & $\mathrm{Et}_{2} \mathrm{O}$ & $\mathrm{DME}$ & room temp. & 2 & $73-84$ \\
9 & $n-\mathrm{BuLi}(1.2)$ & $\mathrm{Et}_{2} \mathrm{O}$ & $\mathrm{TMEDA}$ & room temp. & 2 & $85-92$ \\
\hline
\end{tabular}

${ }^{a}$ Yield of the lithium anion 12 was calculated as $\%$ of deuterium incorporation by ${ }^{1} \mathrm{H}$ NMR spectroscopy after $\mathrm{D}_{2} \mathrm{O}$ quench.

b 2.4 equiv. 
General Information. Infrared (IR) spectra are reported in wave numbers $\left(\mathrm{cm}^{-1}\right)$. The ${ }^{1} \mathrm{H}$ NMR (300 MHz) and ${ }^{13} \mathrm{C}$ NMR $(75 \mathrm{MHz})$ spectra were measured in $\mathrm{CDCl}_{3}$ using $\mathrm{SiMe}_{4}(\delta=0 \mathrm{ppm})$ and the center line of $\mathrm{CDCl}_{3}$ triplet $(\delta=77.1 \mathrm{ppm})$ as internal standards, respectively. The following solvents were distilled before use: THF (from $\mathrm{Na}$ /benzophenone), $\mathrm{Et}_{2} \mathrm{O}$ (from $\mathrm{Na}$ /benzophenone), and $\mathrm{CH}_{2} \mathrm{Cl}_{2}$ (from $\mathrm{CaH}_{2}$ ).

$\left(1 R^{*}, \mathbf{4} R^{*}\right)-4-(P r o p-1-e n-2-y l) c y c l o h e x-2-e n o l ~(5 a) . \quad$ To a solution of $\mathrm{ZnCl}_{2}(1.40$ $\mathrm{g}, 10.3 \mathrm{mmol})$ and TMEDA (1.62 $\mathrm{mL}, 10.8 \mathrm{mmol})$ in THF (3 mL) was added $\mathrm{CH}_{2}=\mathrm{C}(\mathrm{Me}) \mathrm{MgBr}(\mathbf{8})(14.1 \mathrm{~mL}, 0.60 \mathrm{M}$ in THF, $8.46 \mathrm{mmol})$. The mixture was stirred at room temperature for $10 \mathrm{~min}$ to produce $\mathrm{CH}_{2}=\mathrm{C}(\mathrm{Me}) \mathrm{ZnCl}(9)$ for the reaction with 4 . To another ice-cold flask containing $\mathrm{NiCl}_{2}(\mathrm{tpp})_{2}(167 \mathrm{mg}, 0.26 \mathrm{mmol})$ and THF (1 mL) was added $\mathrm{CH}_{2}=\mathrm{C}(\mathrm{Me}) \mathrm{MgBr}(0.86 \mathrm{~mL}, 0.60 \mathrm{M}$ in THF, $0.52 \mathrm{mmol})$. The mixture was stirred at room temperature for $10 \mathrm{~min}$ and cooled to $0{ }^{\circ} \mathrm{C}$. The solution of $\mathrm{CH}_{2}=\mathrm{C}(\mathrm{Me}) \mathrm{ZnCl}(9)$, prepared above, was transferred to it, and the resulting mixture was stirred at room temperature further for $20 \mathrm{~min}$, at which time a solution of monoacetate 4 (400 mg, $2.56 \mathrm{mmol}$ ) in THF (2 mL) was injected. Reaction was carried out overnight, and quenched by addition of sat. $\mathrm{NaHCO}_{3}$. The mixture was extracted with EtOAc three times. The combined organic extracts were dried over $\mathrm{MgSO}_{4}$ and concentrated under reduced pressure. The product was a mixture of $\mathbf{5 a}$ and $\mathbf{1 1}$ in $94: 6$ by ${ }^{1} \mathrm{H}$ NMR spectroscopy, and the desired product $\mathbf{5 a}$ was isolated by chromatography (283 mg, 80\% yield): IR (neat) 3332, 1643, $1057 \mathrm{~cm}^{-1} ;{ }^{1} \mathrm{H}$ NMR $\delta$ 1.39-1.56 (m, 2 H), 1.69 (s, 3 H), 1.82-2.08 (m, 3 H), 2.70-2.79 (m, 1 H), 4.16-4.25 (m, $1 \mathrm{H}), 4.68(\mathrm{~s}, 1 \mathrm{H}), 4.74(\mathrm{~s}, 1 \mathrm{H}), 5.66(\mathrm{dm}, J=10 \mathrm{~Hz}, 1 \mathrm{H}), 5.77$ (ddt, $J=10,1,3 \mathrm{~Hz}, 1$ $\mathrm{H}) ;{ }^{13} \mathrm{C}$ NMR $\delta 147.8,132.4,131.0,110.6,66.4,43.1,31.4,25.6,20.9$.

$\left(1 R^{*}, 2 S^{*}\right)$-2-(Prop-1-en-2-yl)cyclohex-3-enol (11). Regioisomer 11 of the above reaction was also purified: ${ }^{1} \mathrm{H}$ NMR $\delta 1.55-1.65(\mathrm{~m}, 1 \mathrm{H}), 1.70(\mathrm{~s}, 3 \mathrm{H}), 1.89$ (br s, 1 H), 1.94-2.04 (m, 1 H), 2.12-2.21 (m, 2 H), 2.72-2.80 (m, 1 H), 3.68 (ddt, $J=11,8,3$ Hz, 1 H), 4.89 (s, 1 H), 4.93 (br s, 1 H), 5.40 (dq, $J=10,2.5$ Hz, 1 H), 5.68-5.76 (m, 1 $\mathrm{H})$.

2-Iodo-4-(prop-1-en-2-yl)cyclohex-2-enone (14). To an ice-cold solution of alcohol 5a (283 mg, $2.05 \mathrm{mmol})$ in acetone $(4 \mathrm{~mL})$ was added Jones reagent $(0.55 \mathrm{~mL}$, $4.0 \mathrm{M}, 2.2 \mathrm{mmol}$ ) dropwise. After $15 \mathrm{~min}$ of stirring at the same temperature, reaction was quenched by addition of 2-propanol, and the resulting mixture was diluted with 
brine and $\mathrm{CH}_{2} \mathrm{Cl}_{2}$. The layers were separated, and the aqueous layer was extracted with $\mathrm{CH}_{2} \mathrm{Cl}_{2}$ twice. The combined extracts were washed with sat. $\mathrm{NaHCO}_{3}$ and passed through a short Celite column to afford a solution of 4-isopropenyl-2-cyclohexen-1-one for the next reaction.

To the above solution were added 2,5-di-tert-butyl-hydroquinone (14 mg, 0.063 $\mathrm{mmol})$ and a pyridine solution $(4 \mathrm{~mL})$ of $\mathrm{I}_{2}(1.56 \mathrm{~g}, 6.15 \mathrm{mmol})$. The mixture was stirred at room temperature for $2 \mathrm{~h}$ and then diluted with $\mathrm{Et}_{2} \mathrm{O}$ and $\mathrm{H}_{2} \mathrm{O}$. The remaining reagent was quenched with aqueous $\mathrm{Na}_{2} \mathrm{~S}_{2} \mathrm{O}_{3}$ and the product was extracted with EtOAc three times. The combined extracts were dried over $\mathrm{MgSO}_{4}$ and concentrated under reduced pressure to afford an oily residue, which was purified by chromatography (hexane/EtOAc) to furnish $\alpha$-iodo enone $14(407 \mathrm{mg})$ in $76 \%$ yield for 2 steps: IR (neat) 3077, 1683, $898 \mathrm{~cm}^{-1}$; ${ }^{1} \mathrm{H}$ NMR $\delta 1.79$ (s, $\left.3 \mathrm{H}\right), 1.91-2.08$ (m, $1 \mathrm{H}$ ), 2.14-2.26 (m, $1 \mathrm{H}), 2.54$ (dddd, $J=17,11,5,2 \mathrm{~Hz}, 1 \mathrm{H}), 2.68-2.80$ (m, $1 \mathrm{H}$ ), 3.13 (quintet, $J=4 \mathrm{~Hz}, 1 \mathrm{H}$ ), 4.79 (s, $1 \mathrm{H}), 4.92$ (s, $1 \mathrm{H}$ ), 7.63 (br s, $1 \mathrm{H}$ ),${ }^{13} \mathrm{C}$ NMR $\delta 191.9$, $161.1,144.0,113.2,104.0,47.6,35.4,27.8,21.5$.

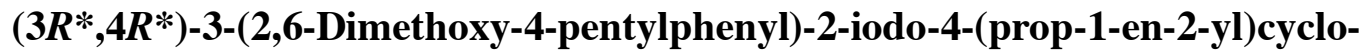

hexanone (15). To an ice-cold solution of the dimethyl ether of olivetol (239 $\mathrm{mg}, 1.15$ mmol) and DME $(0.25 \mathrm{~mL}, 2.44 \mathrm{mmol})$ in $\mathrm{Et}_{2} \mathrm{O}(3 \mathrm{~mL})$ was added $n$-BuLi $(0.49 \mathrm{~mL}$, $2.50 \mathrm{M}$ in hexane, $1.22 \mathrm{mmol}$ ) dropwise. The solution was stirred at $0{ }^{\circ} \mathrm{C}$ for $10 \mathrm{~min}$ and at room temperature for $2 \mathrm{~h}$. The lithium anion 12 thus prepared was transferred into a suspension of $\mathrm{CuCN}(51 \mathrm{mg}, 0.57 \mathrm{mmol})$ in $\mathrm{Et}_{2} \mathrm{O}(3 \mathrm{~mL})$, which had been cooled to $-78{ }^{\circ} \mathrm{C}$. After the addition, the mixture was stirred at $0{ }^{\circ} \mathrm{C}$ for $10 \mathrm{~min}$ and at $-78{ }^{\circ} \mathrm{C}$ for $30 \mathrm{~min}$. To the resulting white suspension were added slowly $\mathrm{BF}_{3} \cdot \mathrm{Et}_{2} \mathrm{O}(0.05 \mathrm{~mL}$, $0.38 \mathrm{mmol})$, and, after $10 \mathrm{~min}$, a solution of $\alpha$-iodo enone $14(100 \mathrm{mg}, 0.382 \mathrm{mmol})$ dissolved in $\mathrm{Et}_{2} \mathrm{O}(1 \mathrm{~mL})$. Reaction was continued at $-78{ }^{\circ} \mathrm{C}$ for $2 \mathrm{~h}$ and terminated by pouring into aqueous $\mathrm{NH}_{3}$ with vigorous stirring. The product was extracted with EtOAc three times. The combined organic extracts were dried over $\mathrm{MgSO}_{4}$ and concentrated under reduced pressure. The residual oil was then subjected to chromatography (hexane/EtOAc) to afford a mixture of $\alpha$-iodo ketone 15 (as $1: 1$ diastereomeric mixtures) and the olivetol ether (ca. $150 \mathrm{mg}$ ): The selected ${ }^{1} \mathrm{H}$ NMR signals: for the 2,3-cis-stereoisomer, $\delta 3.60(\mathrm{dd}, J=10,5.5 \mathrm{~Hz}, 1 \mathrm{H}), 3.69(\mathrm{~s}, 3 \mathrm{H}), 3.78$ $(\mathrm{s}, 3 \mathrm{H}), 4.58(\mathrm{~s}, 1 \mathrm{H}), 4.65$ (br s, $1 \mathrm{H}), 4.87(\mathrm{dd}, J=5,2 \mathrm{~Hz}, 1 \mathrm{H})$; for the 2,3-trans-isomer, $\delta 3.76(\mathrm{~s}, 3 \mathrm{H}), 3.82(\mathrm{~s}, 3 \mathrm{H}), 4.07$ (t, $J=11 \mathrm{~Hz}, 1 \mathrm{H}), 4.44(\mathrm{br} \mathrm{s}, 1 \mathrm{H})$, 4.49 (s, $1 \mathrm{H}), 5.68$ (dd, $J=11,1 \mathrm{~Hz}, 1 \mathrm{H})$. 


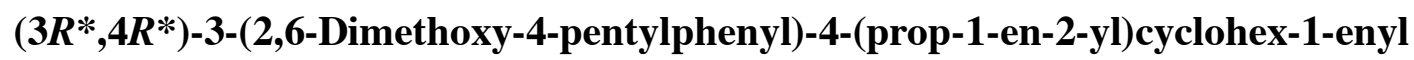

Diethyl Phosphate (16). To an ice-cold solution of the above mixture dissolved in THF (3.2 mL) were added EtMgBr (0.68 mL, 0.70 M in THF, $0.48 \mathrm{mmol})$, and after 10 min, $\mathrm{ClP}(\mathrm{O})(\mathrm{OEt})_{2}(0.12 \mathrm{~mL}, 0.80 \mathrm{mmol})$. Reaction was carried out at $0{ }^{\circ} \mathrm{C}$ for $2 \mathrm{~h}$ and quenched by addition of sat. $\mathrm{NaHCO}_{3}$. The product was extracted with EtOAc three times. The combined extracts were dried over $\mathrm{MgSO}_{4}$ and concentrated under reduced pressure to afford an oily residue, which was purified by chromatography (hexane/EtOAc) to furnish enol phosphate $\mathbf{1 6}(93 \mathrm{mg})$ in $51 \%$ yield from $\alpha$-iodo enone 14: IR (neat) $1608,1581,1119,1034 \mathrm{~cm}^{-1} ;{ }^{1} \mathrm{H}$ NMR $\delta 0.88(\mathrm{t}, J=7 \mathrm{~Hz}, 3 \mathrm{H})$, $1.26-1.36(\mathrm{~m}, 10 \mathrm{H}), 1.58$ (s, $3 \mathrm{H}), 1.49-1.64$ (m, $2 \mathrm{H}), 1.74-1.92$ (m, $2 \mathrm{H}), 2.22-2.34$ (m, $1 \mathrm{H}), 2.40-2.58(\mathrm{~m}, 3 \mathrm{H}), 2.85(\mathrm{dt}, J=5,11 \mathrm{~Hz}, 2 \mathrm{H}), 3.71(\mathrm{~s}, 3 \mathrm{H}), 4.05-4.18(\mathrm{~m}, 5$ H), 4.38 (br s, $1 \mathrm{H}), 4.43$ (br s, $1 \mathrm{H}), 5.31$ (q, $J=2 \mathrm{~Hz}, 1 \mathrm{H}), 6.29(\mathrm{~s}, 2 \mathrm{H}) ;{ }^{13} \mathrm{C}$ NMR $\delta$ 158.5, 147.9, $145.4(\mathrm{~d}, J=9 \mathrm{~Hz}), 142.3,116.9,116.1(\mathrm{~d}, J=6 \mathrm{~Hz}), 110.4,104.3,63.9$ $(\mathrm{d}, J=6 \mathrm{~Hz}), 55.7,44.8,36.5,34.5,31.7,31.1,29.1,28.3$ (d, $J=3 \mathrm{~Hz}), 22.7,19.0,16.2$ (d, $J=7 \mathrm{~Hz}), 14.2$.

\section{1,3-Dimethoxy-2-((1R*,6R*)-3-methyl-6-(prop-1-en-2-yl)cyclohex-2-enyl)-5-} pentylbenzene (17). To an ice-cold solution of $\mathrm{Ni}(\mathrm{acac})_{2}(3.2 \mathrm{mg}, 0.0125 \mathrm{mmol})$ in THF ( $1 \mathrm{~mL})$ were added $\mathrm{MeMgCl}(0.05 \mathrm{~mL}, 3.0 \mathrm{M}$ in THF, $0.15 \mathrm{mmol})$, and, after 10 min, a solution of enol phosphate 16 (30 mg, $0.0624 \mathrm{mmol})$ dissolved in THF (1 mL). The solution was stirred at room temperature overnight, and diluted with sat. $\mathrm{NaHCO}_{3}$. The mixture was extracted with EtOAc three times. The combined organic layers were dried over $\mathrm{MgSO}_{4}$ and concentrated under reduced pressure. An oily residue obtained was purified by chromatography (hexane) to furnish dimethyl ether $\mathbf{1 7}(18 \mathrm{mg})$ in $84 \%$ yield: IR (neat) $1608,1581,1119 \mathrm{~cm}^{-1} ;{ }^{1} \mathrm{H}$ NMR $\delta 0.90(\mathrm{t}, J=7 \mathrm{~Hz}, 3 \mathrm{H}), 1.24-1.42$ (m, $4 \mathrm{H}), 1.60$ (s, $3 \mathrm{H}), 1.67$ (s, $3 \mathrm{H}), 1.46-1.82$ (m, $4 \mathrm{H}), 1.92-2.03$ (m, 1 H), 2.10-2.28 (m, $1 \mathrm{H}), 2.54(\mathrm{t}, J=7 \mathrm{~Hz}, 2 \mathrm{H}), 2.90(\mathrm{dt}, J=5,11 \mathrm{~Hz}, 1 \mathrm{H}), 3.73(\mathrm{~s}, 6 \mathrm{H}), 3.94-4.04$ (m, $1 \mathrm{H}), 4.40-4.47$ (m, $2 \mathrm{H}), 5.20$ (br s, $1 \mathrm{H}), 6.33$ (s, $2 \mathrm{H}) ;{ }^{13} \mathrm{C}$ NMR $\delta$ 158.7, 149.5, $141.8,131.2$, 125.9, 119.0, 109.6, 105.0, 56.1 , 45.3, 36.6, 36.3, 31.9, 31.2, 30.9, 29.9, 23.6, 22.8, 19.3, 14.3.

\section{1,3-Dimethoxy-2-((1R*,6R*)-3-((dimethyl(isopropoxy)silyl)methyl)-6-(prop-1-} en-2-yl)cyclohex-2-enyl)-5-penylbenzene (18). To an ice-cold solution of $\mathrm{Ni}(\mathrm{acac})_{2}$ (4.9 mg, $0.019 \mathrm{mmol})$ in THF (1 mL) were added $\mathrm{ClMgCH}_{2} \mathrm{Si}\left(\mathrm{CH}_{3}\right)_{2}(\mathrm{O}-i$-Pr $)(0.30 \mathrm{~mL}$, $0.81 \mathrm{M}$ in THF, $0.24 \mathrm{mmol}$ ), and, after $10 \mathrm{~min}$, a solution of enol phosphate 16 (46 $\mathrm{mg}$, $0.096 \mathrm{mmol})$ dissolved in THF $(1 \mathrm{~mL})$. The solution was stirred at room temperature 
overnight, and diluted with sat. $\mathrm{NaHCO}_{3}$. The product was isolated as described above for 17, and purified by chromatography (hexane) to furnish $\mathbf{1 8}(35 \mathrm{mg})$ in $80 \%$ yield: IR (neat) 1608, 1581, 1119, $1026 \mathrm{~cm}^{-1}$; ${ }^{1} \mathrm{H}$ NMR $\delta 0.12$ (s, $\left.3 \mathrm{H}\right), 0.17$ (s, $3 \mathrm{H}$ ), 0.91 (t, $J$ $=7 \mathrm{~Hz}, 3 \mathrm{H}), 1.14(\mathrm{~s}, 3 \mathrm{H}), 1.16(\mathrm{~s}, 3 \mathrm{H}), 1.25-1.42(\mathrm{~m}, 4 \mathrm{H}), 1.59$ (s, $3 \mathrm{H}), 1.45-1.78$ (m, $4 \mathrm{H}), 1.92-2.04(\mathrm{~m}, 1 \mathrm{H}), 2.15-2.34(\mathrm{~m}, 1 \mathrm{H}), 2.53(\mathrm{t}, J=8 \mathrm{~Hz}, 3 \mathrm{H}), 2.93$ (dt, $J=4$, $11 \mathrm{~Hz}, 1 \mathrm{H}), 3.73$ (s, $6 \mathrm{H}), 3.93-4.08$ (m, $2 \mathrm{H}), 4.43$ (br s, $2 \mathrm{H}), 5.09$ (br s, $1 \mathrm{H}), 6.32$ (s, $2 \mathrm{H}) ;{ }^{13} \mathrm{C}$ NMR $\delta 158.7,149.6,141.7,131.3,124.8,118.6,109.5,104.5,64.9,55.9,45.0$, $36.6,36.5,32.0,31.9,31.2,30.2,27.7,26.0,22.8,19.3,14.3,-0.9,-1.3$.

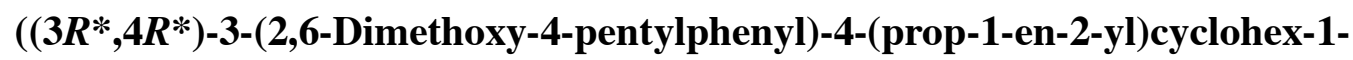
enyl)methanol (19). A mixture of 18 (30 mg, $0.065 \mathrm{mmol}), \mathrm{KHCO}_{3}(39 \mathrm{mg}, 0.39$ $\mathrm{mmol})$, and $\mathrm{KF}$ (23 mg, $0.40 \mathrm{mmol})$ in THF (1 mL) and $\mathrm{MeOH}(1 \mathrm{~mL})$ was stirred at $50{ }^{\circ} \mathrm{C}$ for $10 \mathrm{~min}$ to prepare a solution. Reaction was carried out with $35 \% \mathrm{H}_{2} \mathrm{O}_{2}(0.08$ $\mathrm{mL}, 0.97 \mathrm{mmol})$ at $50{ }^{\circ} \mathrm{C}$ for $4 \mathrm{~h}$, and then with additional $35 \% \mathrm{H}_{2} \mathrm{O}_{2}(0.05 \mathrm{~mL}, 0.65$ mmol) further for $1 \mathrm{~h}$. The mixture was cooled to room temperature and poured into sat. $\mathrm{Na}_{2} \mathrm{~S}_{2} \mathrm{O}_{3}$ and EtOAc with vigorous stirring. After $1 \mathrm{~h}$ of stirring, the organic layer was separated, and the aqueous layer was extracted with EtOAc twice. The combined organic layers were dried over $\mathrm{MgSO}_{4}$ and concentrated under reduced pressure to afford an oily residue, which was purified by chromatography (hexane/EtOAc) to furnish alcohol 19 (18 mg) in 77\% yield: IR (neat) $3391,1608,1581,1119 \mathrm{~cm}^{-1} ;{ }^{1} \mathrm{H}$ NMR $\delta 0.90(\mathrm{t}, J=7 \mathrm{~Hz}, 3 \mathrm{H}), 1.27-1.38(\mathrm{~m}, 4 \mathrm{H}), 1.61$ (s, $3 \mathrm{H}), 1.54-1.88$ (m, $5 \mathrm{H})$, 2.10-2.34 (m, $2 \mathrm{H}), 2.53$ (t, $J=7.5 \mathrm{~Hz}, 2 \mathrm{H}), 3.73$ (s, $6 \mathrm{H}), 4.01(\mathrm{~s}, 2 \mathrm{H}), 3.98-4.07$ (m, $1 \mathrm{H}), 4.41$ (br s, $1 \mathrm{H}), 4.45$ (br s, $1 \mathrm{H}), 5.51$ (br s, $1 \mathrm{H}), 6.33$ (s, $2 \mathrm{H}) ;{ }^{13} \mathrm{C}$ NMR $\delta 158.5$, 149.0, 142.2, 134.9, 128.6, 117.9, 109.9, 104.8, 67.8, 55.9, 45.6, 36.6, 36.0, 31.8, 31.2, $29.5,26.5,22.7,19.2,14.3$.

$\left(1 R^{*}, \mathbf{4} R^{*}\right)$-4-(Hept-1-en-2-yl)cyclohex-2-enol (5b). To a mixture of $\mathrm{ZnCl}_{2}(131$ $\mathrm{mg}, 0.961 \mathrm{mmol})$ and TMEDA $(0.144 \mathrm{~mL}, 0.958 \mathrm{mmol})$ in THF $(0.5 \mathrm{~mL})$ was added a slution of $\mathrm{CH}_{2}=\mathrm{C}\left(\mathrm{C}_{5} \mathrm{H}_{11}\right) \mathrm{MgBr}(1.20 \mathrm{~mL}, 0.64 \mathrm{M}$ in THF, $0.768 \mathrm{mmol})$ to prepare $\mathrm{CH}_{2}=\mathrm{C}\left(\mathrm{C}_{5} \mathrm{H}_{11}\right) \mathrm{ZnCl}$ (20) (room temperature, $10 \mathrm{~min}$ ). On the other hand, $\mathrm{CH}_{2}=\mathrm{C}\left(\mathrm{C}_{5} \mathrm{H}_{11}\right) \mathrm{MgBr}(0.15 \mathrm{~mL}, 0.64 \mathrm{M}$ in THF, $0.096 \mathrm{mmol})$ was added to another flask containing $\mathrm{NiCl}_{2}(\mathrm{tpp})_{2}(25 \mathrm{mg}, 0.038 \mathrm{mmol})$ in THF $(0.5 \mathrm{~mL})$. After $5 \mathrm{~min}$ of stirring at room temperature, the zinc reagent 20 prepared above was added. The mixture was stirred $10 \mathrm{~min}$ before addition of monoacetate 4 (30 $\mathrm{mg}, 0.192 \mathrm{mmol}$ ). The resulting mixture was stirred at room temperature for $24 \mathrm{~h}$ and diluted with sat. $\mathrm{NH}_{4} \mathrm{Cl}$ and EtOAc with vigorous stirring. The layers were separated, and the aqueous layer was 
extracted with EtOAc. The combined extracts were dried and concentrated to leave an oil, which was a mixture of $\mathbf{5 b}$ and its regioisomer in $94: 6$ by ${ }^{1} \mathrm{H}$ NMR spectroscopy. Chromatography of the mixture afforded $\mathbf{5 b}(32 \mathrm{mg})$ in $86 \%$ yield: IR (neat) 3338 , 1055, $892 \mathrm{~cm}^{-1}$; ${ }^{1} \mathrm{H}$ NMR $\delta 0.89$ (t, $\left.J=7 \mathrm{~Hz}, 3 \mathrm{H}\right), 1.19-1.57(\mathrm{~m}, 8 \mathrm{H}), 1.67$ (br s, $\left.1 \mathrm{H}\right)$, 1.86-2.09 (m, 4 H), 2.72-2.80 (m, 1 H), 4.17-4.26 (br s, 1 H), 4.71 (br s, 1 H), 4.76 (q, $J=2 \mathrm{~Hz}, 1 \mathrm{H}), 5.68(\mathrm{dm}, J=10 \mathrm{~Hz}, 1 \mathrm{H}), 5.78(\mathrm{ddt}, J=10,1,3 \mathrm{~Hz}, 1 \mathrm{H}) ;{ }^{13} \mathrm{C}$ NMR $\delta$ $152.3,133.1,130.8,109.6,66.6,42.0,35.0,32.1,31.6,28.1,26.3,23.0,14.5$.

$\left(1 R^{*}, 2 S^{*}\right)$-2-(Hept-1-en-2-yl)cyclohex-3-enol (Regioisomer of 5b). The title compound was produced as a minor compound of the above reaction: ${ }^{1} \mathrm{H}$ NMR $\delta 0.89$ (t, $J=7$ Hz, 3 H), 1.17-1.68 (m, 9 H), 1.82 (br s, 1 H), 1.92-2.06 (m, 3 H), 2.12-2.22 (m, 2 H), 2.72-2.81 (m, $1 \mathrm{H}), 3.71$ (ddd, $J=10,8,3 \mathrm{~Hz}, 1 \mathrm{H}), 4.92(\mathrm{~s}, 1 \mathrm{H}), 4.93$ (q, $J=$ $1.5 \mathrm{~Hz}, 1 \mathrm{H}), 5.40(\mathrm{dq}, J=10,2 \mathrm{~Hz}, 1 \mathrm{H}), 5.67-5.76(\mathrm{~m}, 1 \mathrm{H})$.

4-(Hept-1-en-2-yl)cyclohex-2-enone. To an ice-cold solution of alcohol $\mathbf{5 b}$ (353 $\mathrm{mg}, 1.82 \mathrm{mmol})$ in acetone $(2.3 \mathrm{~mL})$ was added Jones reagent $(0.47 \mathrm{~mL}, 4.0 \mathrm{M}, 1.88$ mmol) dropwise. After $15 \mathrm{~min}$ of stirring at $0{ }^{\circ} \mathrm{C}, 2$-propanol was added to destroy the remaining reagent. The reaction mixture was diluted with $\mathrm{H}_{2} \mathrm{O}$ and $\mathrm{CH}_{2} \mathrm{Cl}_{2}$. The layers were separated, and the aqueous layer was extracted with $\mathrm{CH}_{2} \mathrm{Cl}_{2}$ twice. The combined extracts were washed with sat. $\mathrm{NaHCO}_{3}$, dried over $\mathrm{MgSO}_{4}$, and concentrated to leave an oil, which was used for the next reaction without further purification. An analytically pure sample was obtained by chromatography: IR (neat) $1686,897 \mathrm{~cm}^{-1}$; ${ }^{1} \mathrm{H}$ NMR $\delta 0.89$ (t, $\left.J=7 \mathrm{~Hz}, 3 \mathrm{H}\right), 1.19-1.59$ (m, $6 \mathrm{H}$ ), 1.90 (dddd, $J=13,10.5,8,4.5$ $\mathrm{Hz}, 1 \mathrm{H}), 2.07$ (t, $J=7.5 \mathrm{~Hz}, 2 \mathrm{H}), 2.10-2.22$ (m, $1 \mathrm{H}), 2.34$ (ddd, $J=17,10.5,5 \mathrm{~Hz}, 1$ H), 2.49 (ddd, $J=17,7,4$ Hz, $1 \mathrm{H}), 3.00-3.08$ (m, $1 \mathrm{H}), 4.79$ (s, $1 \mathrm{H}), 4.90$ (br s, $1 \mathrm{H})$, $6.03(\mathrm{dd}, J=10,2 \mathrm{~Hz}, 1 \mathrm{H}), 6.84(\mathrm{dd}, J=10,3 \mathrm{~Hz}, 1 \mathrm{H}) ;{ }^{13} \mathrm{C}$ NMR $\delta 199.5,152.9$, $149.6,129.4,111.2,42.2,36.5,35.3,31.7,28.6,27.8,22.7,14.2$.

4-(Hept-1-en-2-yl)-2-iodocyclohex-2-enone (21). To an ice-cold solution of the above enone and 2,5-di-tert-butylhydro-quinone (12 $\mathrm{mg}, 0.054 \mathrm{mmol})$ in $\mathrm{CH}_{2} \mathrm{Cl}_{2}(5 \mathrm{~mL})$ and pyridine $(5 \mathrm{~mL})$ was added $\mathrm{I}_{2}(1.38 \mathrm{~g}, 5.44 \mathrm{mmol})$. The mixture was stirred at room temperature for $2 \mathrm{~h}$, and diluted with $\mathrm{Et}_{2} \mathrm{O}$ and $\mathrm{H}_{2} \mathrm{O}$. After vigorous stirring for $10 \mathrm{~min}$ at room temperature, aqueous $\mathrm{Na}_{2} \mathrm{~S}_{2} \mathrm{O}_{3}$ was added, and the mixture was extracted with EtOAc three times. The combined extracts were dried over $\mathrm{MgSO}_{4}$ and concentrated under reduced pressure. A residue obtained was purified by chromatography (hexane/EtOAc) to furnish $\alpha$-iodo enone $21(357 \mathrm{mg})$ in $56 \%$ yield 
from alcohol 5b: $\quad$ IR (neat) $1685,895 \mathrm{~cm}^{-1} ;{ }^{1} \mathrm{H}$ NMR $\delta 0.91(\mathrm{t}, J=7 \mathrm{~Hz}, 3 \mathrm{H})$, 1.24-1.54 (m, $6 \mathrm{H}), 1.91-2.04(\mathrm{~m}, 1 \mathrm{H}), 2.08$ (t, $J=7 \mathrm{~Hz}, 2 \mathrm{H}), 2.17-2.30$ (m, $1 \mathrm{H})$, $2.55(\mathrm{ddd}, J=16.5,10.5,4.5 \mathrm{~Hz}, 1 \mathrm{H}), 2.76(\mathrm{ddd}, J=16.5,7,4 \mathrm{~Hz}, 1 \mathrm{H}), 3.14$ (quintet, $J=4 \mathrm{~Hz}, 1 \mathrm{H}), 4.83($ br s, $1 \mathrm{H}), 4.95($ br s, $1 \mathrm{H}), 7.64(\mathrm{dd}, J=4,0.6 \mathrm{~Hz}, 1 \mathrm{H}) ;{ }^{13} \mathrm{C} \mathrm{NMR}$ $\delta 191.8,161.3,148.4,111.9,103.6,46.3,35.2,35.0,31.5,28.3,27.6,22.5,14.1$.

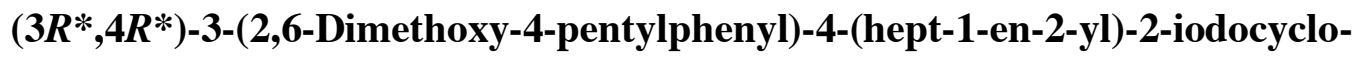
hexanone (22). To an ice-cold solution of the dimethyl ether of olivetol (196 mg, $0.941 \mathrm{mmol})$ and DME $(0.16 \mathrm{~mL}, 1.5 \mathrm{mmol})$ in $\mathrm{Et}_{2} \mathrm{O}(3 \mathrm{~mL})$ was added $n$-BuLi $(0.53$ $\mathrm{mL}, 1.90 \mathrm{M}$ in hexane, $1.01 \mathrm{mmol}$ ) dropwise. The solution was stirred at room temperature for $2 \mathrm{~h}$ to prepare the lithium anion 12, which was added to a suspension of $\mathrm{CuCN}(42 \mathrm{mg}, 0.47 \mathrm{mmol})$ in $\mathrm{Et}_{2} \mathrm{O}(1 \mathrm{~mL})$ at $-78{ }^{\circ} \mathrm{C}$. The mixture was stirred at $0{ }^{\circ} \mathrm{C}$ for $10 \mathrm{~min}$ and then cooled to $-78{ }^{\circ} \mathrm{C}$. After $30 \mathrm{~min}$ of stirring at $-78{ }^{\circ} \mathrm{C}, \mathrm{BF}_{3} \cdot \mathrm{Et}_{2} \mathrm{O}$ $(0.04 \mathrm{~mL}, 0.32 \mathrm{mmol})$ and a solution of $\alpha$-iodo enone 21 (100 $\mathrm{mg}, 0.314 \mathrm{mmol})$ dissolved in $\mathrm{Et}_{2} \mathrm{O}(1 \mathrm{~mL})$ were added to the white slurry. The reaction was continued at $-78{ }^{\circ} \mathrm{C}$ for $2 \mathrm{~h}$ and quenched by pouring into aqueous $\mathrm{NH}_{3}$ with vigorous stirring. The product was extracted with EtOAc three times, and the combined organic extracts were dried over $\mathrm{MgSO}_{4}$ and concentrated under reduced pressure. The oily residue obtained was subjected to chromatography (hexane/EtOAc) to afford a mixture of $\alpha$-iodo ketone 22 (as $1: 1$ diastereometric mixtures) and the olivetol ether. The characteristic signals of ${ }^{1} \mathrm{H}$ NMR $\delta 4.51,4.65$, and 4.68 (3 s, $2 \mathrm{H}$ for olefinic protons), 4.93 and 5.71 (2 dd, $J=5,1$ and 11, $1 \mathrm{~Hz}, 1 \mathrm{H}$ for $\mathrm{C}(2)-\mathrm{H}), 6.26-6.37$ (m, $2 \mathrm{H}$ ).

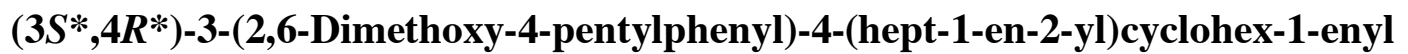

Diethyl Phosphate (23). To an ice-cold solution of the above mixture dissolved in THF ( $1 \mathrm{~mL})$ were added EtMgBr $(0.61 \mathrm{~mL}, 0.78 \mathrm{M}$ in THF, $0.476 \mathrm{mmol})$, and after 10 min, $\mathrm{ClP}(\mathrm{O})(\mathrm{OEt})_{2}(0.11 \mathrm{~mL}, 0.78 \mathrm{mmol})$. Reaction was continued at $0{ }^{\circ} \mathrm{C}$ for $2 \mathrm{~h}$ and quenched by addition of sat. $\mathrm{NaHCO}_{3}$. The product was extracted with EtOAc three times. The combined extracts were dried over $\mathrm{MgSO}_{4}$ and concentrated under reduced pressure to afford an oily residue, which was purified by chromatography (hexane/EtOAc) to furnish enol phosphate $23(83 \mathrm{mg})$ in $49 \%$ yield from $\alpha$-iodo enone 21: IR (neat) 1608, 1581, 1120, $1034 \mathrm{~cm}^{-1} ;{ }^{1} \mathrm{H}$ NMR $\delta 0.82$ (t, $\left.J=7 \mathrm{~Hz}, 3 \mathrm{H}\right), 0.89$ (t, $J=7 \mathrm{~Hz}, 3 \mathrm{H}), 1.01-1.43$ (m, 16 H), 1.53-1.65 (m, 2 H), 1.67-1.89 (m, 4 H), 2.21-2.34 (m, $1 \mathrm{H}), 2.40-2.57(\mathrm{~m}, 3 \mathrm{H}), 4.06-4.20(\mathrm{~m}, 5 \mathrm{H}), 4.52$ (s, $1 \mathrm{H}), 4.63(\mathrm{~s}, 1 \mathrm{H}), 5.32$ (q, $J$ $=2 \mathrm{~Hz}, 1 \mathrm{H}), 6.28(\mathrm{~s}, 2 \mathrm{H}) ;{ }^{13} \mathrm{C}$ NMR $\delta 158.5,152.5,145.5(\mathrm{~d}, J=9 \mathrm{~Hz}), 142.3,117.1$, $116.4(\mathrm{~d}, J=6 \mathrm{~Hz}), 108.2$, 104.4, 64.0 (d, $J=6 \mathrm{~Hz}), 55.7$, 43.4, 36.6, 35.3, 34.5, 31.83, 
31.80, 31.2, 30.2, $28.7(\mathrm{~d}, J=3 \mathrm{~Hz}), 27.5,22.8,22.7,16.3(\mathrm{~d}, J=7 \mathrm{~Hz}), 14.26,14.24$.

1,3-Dimethoxy-2-((1R*,6R*)-6-(hept-1-en-2-yl)-3-methylcyclohex-2-enyl)-5pentylbenzene (24). To an ice-cold solution of $\mathrm{Ni}(\mathrm{acac})_{2}(3 \mathrm{mg}, 0.011 \mathrm{mmol})$ in THF $(1 \mathrm{~mL})$ were added $\mathrm{MeMgCl}(0.05 \mathrm{~mL}, 3.0 \mathrm{M}$ in THF, $0.15 \mathrm{mmol})$, and, after $10 \mathrm{~min}$, a solution of enol phosphate 23 (30 mg, $0.056 \mathrm{mmol})$ in THF $(1 \mathrm{~mL})$. The mixture was stirred at room temperature overnight, and diluted with sat. $\mathrm{NaHCO}_{3}$. The product was extracted with EtOAc three times. The combined organic layers were dried over $\mathrm{MgSO}_{4}$ and concentrated under reduced pressure. An oily product obtained was purified by chromatography (hexane) to furnish $\mathbf{2 4}(19 \mathrm{mg})$ in $85 \%$ yield: IR (neat) $1608,1580,1120 \mathrm{~cm}^{-1} ;{ }^{1} \mathrm{H}$ NMR $\delta 0.83(\mathrm{t}, J=7 \mathrm{~Hz}, 3 \mathrm{H}), 0.91(\mathrm{t}, J=7 \mathrm{~Hz}, 3 \mathrm{H})$, 1.04-1.44 (m, 12 H), 1.67 (s, 3 H), 1.50-1.90 (m, 4 H), 1.90-2.04 (m, 1 H), 2.10-2.26 $(\mathrm{m}, 1 \mathrm{H}), 2.53(\mathrm{t}, J=8 \mathrm{~Hz}, 2 \mathrm{H}), 2.79-2.91(\mathrm{~m}, 1 \mathrm{H}), 3.72(\mathrm{~s}, 6 \mathrm{H}), 3.97-4.07(\mathrm{~m}, 1 \mathrm{H})$, 4.51 (s, $1 \mathrm{H}), 4.64$ (s, $1 \mathrm{H}), 5.21$ (br s, $1 \mathrm{H}), 6.32$ (s, $2 \mathrm{H}) ;{ }^{13} \mathrm{C}$ NMR $\delta$ 158.7, 153.9, 141.8, 131.0, 126.2, 119.1, 107.5, 104.9, 56.0, 43.9, 37.0, 36.6, 34.5, 31.91, 31.85, $31.27,31.22,30.9,27.6,23.6,22.82,22.76,14.30,14.27$.

\section{1,3-Dimethoxy-2-((1R*,6R*)-3-((dimethyl(isopropoxy)silyl)methyl)-6-(hept-1-} en-2-yl)cyclohex-2-enyl)-5-penylbenzene (25). To an ice-cold solution of $\mathrm{Ni}(\mathrm{acac})_{2}$ (4 mg, $0.015 \mathrm{mmol})$ in THF $(0.5 \mathrm{~mL})$ were added $\mathrm{ClMgCH}_{2} \mathrm{Si}\left(\mathrm{CH}_{3}\right)_{2}(\mathrm{O}-i$ - $\mathrm{Pr})(0.23 \mathrm{~mL}$, $0.81 \mathrm{M}$ in THF, $0.19 \mathrm{mmol}$ ), and after $10 \mathrm{~min}$, a solution of enol phosphate 23 (40 $\mathrm{mg}$, $0.075 \mathrm{mmol})$ dissolved in THF $(1 \mathrm{~mL})$. The mixture was stirred at room temperature overnight, and diluted with sat. $\mathrm{NaHCO}_{3}$. The product was extracted with EtOAc three times. The combined organic layers were dried over $\mathrm{MgSO}_{4}$ and concentrated under reduced pressure to afford an oily residue, which was purified by chromatography (hexane) to furnish $25(31 \mathrm{mg})$ in $81 \%$ yield: IR (neat) 1608, 1581, 1120, $1027 \mathrm{~cm}^{-1}$; ${ }^{1} \mathrm{H}$ NMR $\delta 0.11(\mathrm{~s}, 3 \mathrm{H}), 0.16(\mathrm{~s}, 3 \mathrm{H}), 0.82(\mathrm{t}, J=7 \mathrm{~Hz}, 3 \mathrm{H}), 0.90(\mathrm{t}, J=7 \mathrm{~Hz}, 3 \mathrm{H})$, $1.14(\mathrm{~d}, J=6 \mathrm{~Hz}, 3 \mathrm{H}), 1.02-1.38(\mathrm{~m}, 13 \mathrm{H}), 1.44-1.70(\mathrm{~m}, 4 \mathrm{H}), 1.74-1.88(\mathrm{~m}, 2 \mathrm{H})$, 1.91-2.02 (m, $1 \mathrm{H}), 2.14-2.32(\mathrm{~m}, 1 \mathrm{H}), 2.52(\mathrm{t}, J=8 \mathrm{~Hz}, 2 \mathrm{H}), 2.80-2.92(\mathrm{~m}, 1 \mathrm{H})$, $3.71(\mathrm{~s}, 6 \mathrm{H}), 3.94-4.08$ (m, $2 \mathrm{H}), 4.49$ (s, $1 \mathrm{H}), 4.63$ (s, $1 \mathrm{H}), 5.09$ (br s, $1 \mathrm{H}), 6.30$ (s, 2 $\mathrm{H}) ;{ }^{13} \mathrm{C}$ NMR $\delta 158.6,154.0,141.7,131.2,125.1,118.7,107.4,104.4,64.9,55.9,43.5$, 37.2 , 36.6, 34.6, 32.4, 31.9, 31.25, 31.22, 27.7, 27.5, 26.0, 22.82, 22.76, 14.30, 14.27, $-0.9,-1.3$.

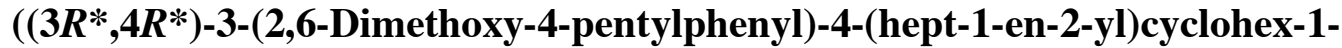
enyl)methanol (26). A mixture of 25 (22 mg, $0.043 \mathrm{mmol}), \mathrm{KHCO}_{3}(26 \mathrm{mg}, 0.26$ 
$\mathrm{mmol})$, and $\mathrm{KF}(15 \mathrm{mg}, 0.26 \mathrm{mmol})$ in THF $(1 \mathrm{~mL})$ and $\mathrm{MeOH}(1 \mathrm{~mL})$ was dissolved in it by stirring at $50{ }^{\circ} \mathrm{C}$ for $10 \mathrm{~min}$. To this solution was added $35 \% \mathrm{H}_{2} \mathrm{O}_{2}(0.05 \mathrm{~mL}$, $0.64 \mathrm{mmol}$ ). The reaction mixture was stirred at $50{ }^{\circ} \mathrm{C}$ for $4 \mathrm{~h}$, cooled to $0{ }^{\circ} \mathrm{C}$, and diluted with sat. $\mathrm{Na}_{2} \mathrm{~S}_{2} \mathrm{O}_{3}$ and EtOAc. The resulting mixture was stirred vigorously, and the layers were separated. The aqueous layer was extracted with EtOAc three times. The combined organic layers were dried over $\mathrm{MgSO}_{4}$ and concentrated under reduced pressure to afford an oily residue, which was purified by chromatography (hexane/EtOAc) to furnish alcohol 26 (13 mg) in 73\% yield: IR (neat) 3392, 1608, 1580, $1119 \mathrm{~cm}^{-1}$; ${ }^{1} \mathrm{H}$ NMR $\delta 0.83(\mathrm{t}, J=7 \mathrm{~Hz}, 3 \mathrm{H}), 0.90(\mathrm{t}, J=7 \mathrm{~Hz}, 3 \mathrm{H}), 1.03-1.43$ (m, 12 H), 1.54-1.93 (m, 8 H), 2.09-2.33 (m, 2 H), 2.53 (t, $J=8$ Hz, 2 H), 2.78-2.90 (m, $1 \mathrm{H}), 3.72(\mathrm{~s}, 6 \mathrm{H}), 4.00(\mathrm{~s}, 2 \mathrm{H}), 4.01-4.12(\mathrm{~m}, 1 \mathrm{H}), 4.53(\mathrm{~s}, 1 \mathrm{H}), 4.64(\mathrm{~s}, 1 \mathrm{H})$, 5.51 (br s, $1 \mathrm{H}), 6.32$ (s, $2 \mathrm{H}) ;{ }^{13} \mathrm{C}$ NMR $\delta$ 158.6, 153.4, 142.2, 134.9, 128.8, 118.0, $107.8,104.7,67.8,55.8,44.0,36.8,36.6,34.5,31.9,31.8,31.2$, 30.5, 27.5, 26.9, 22.8, $22.7,14.3,14.2$. 


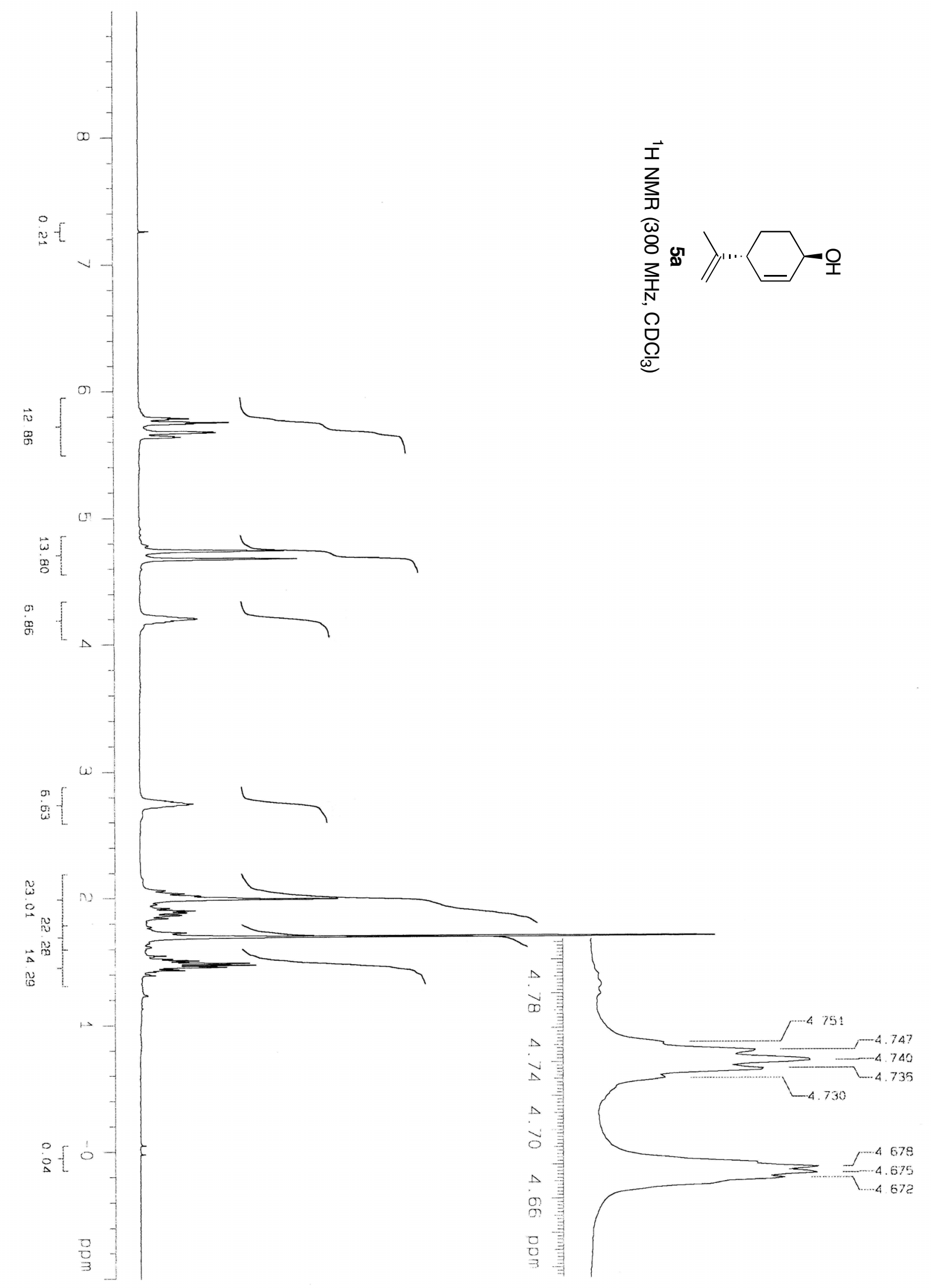




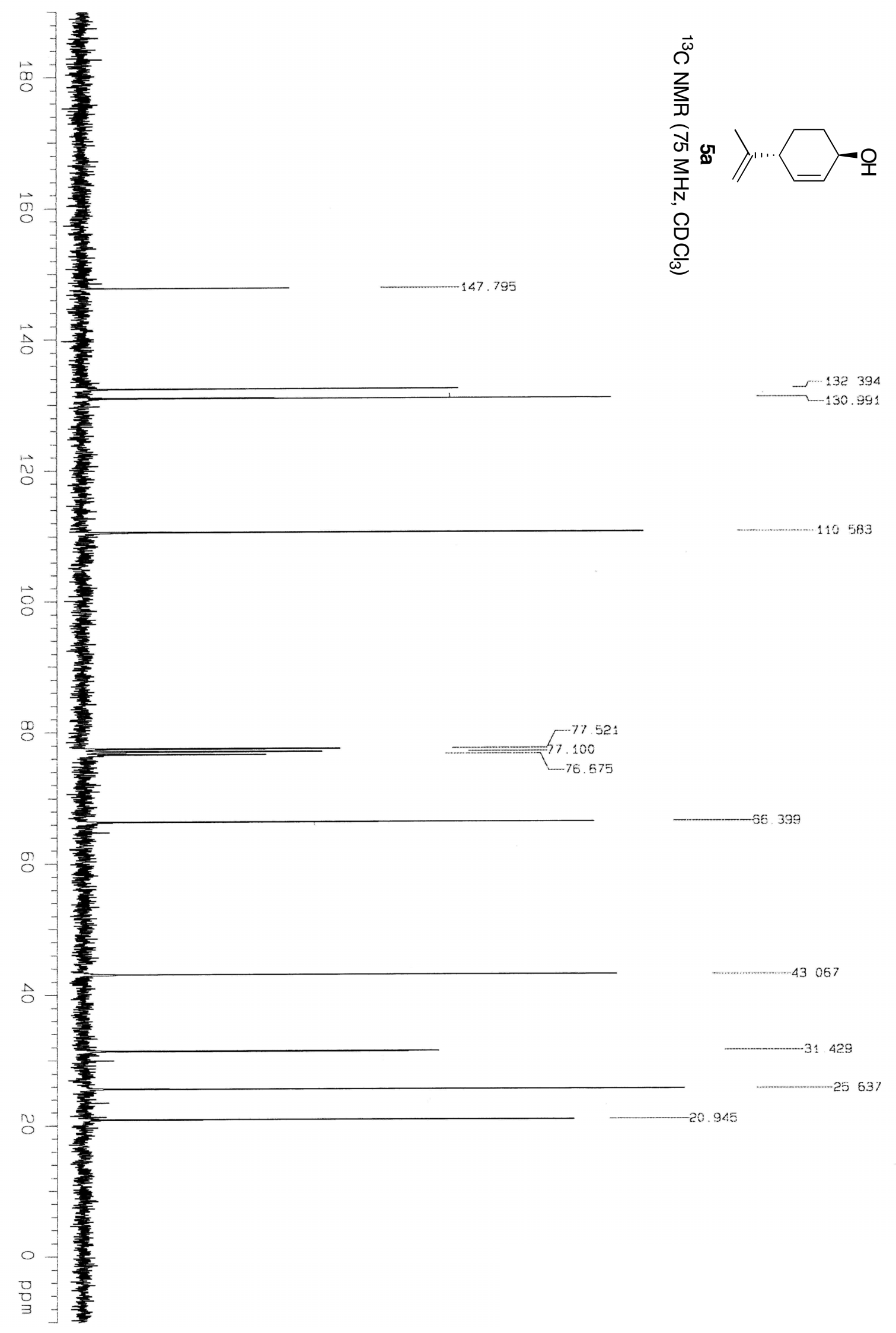

S-12 


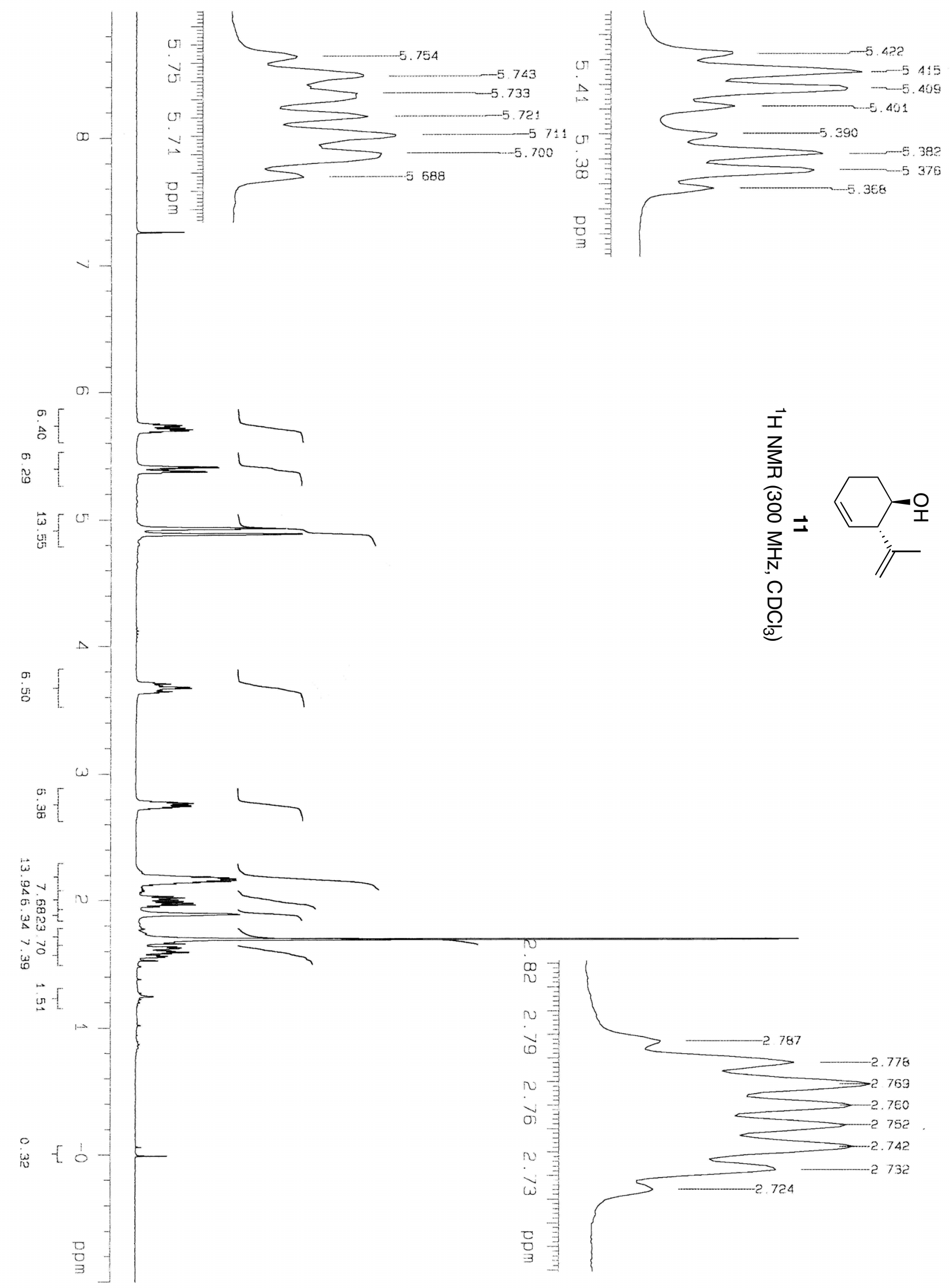



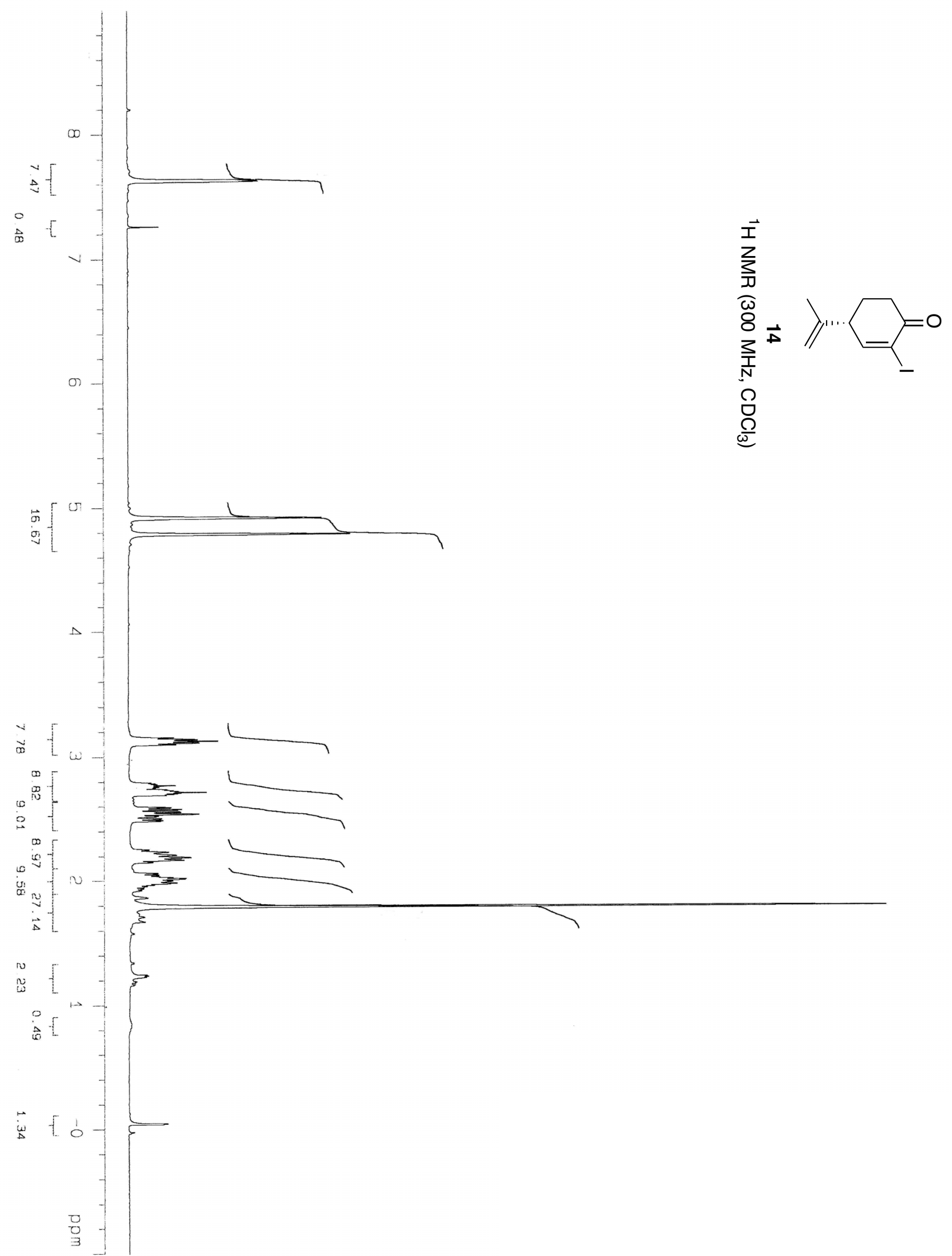


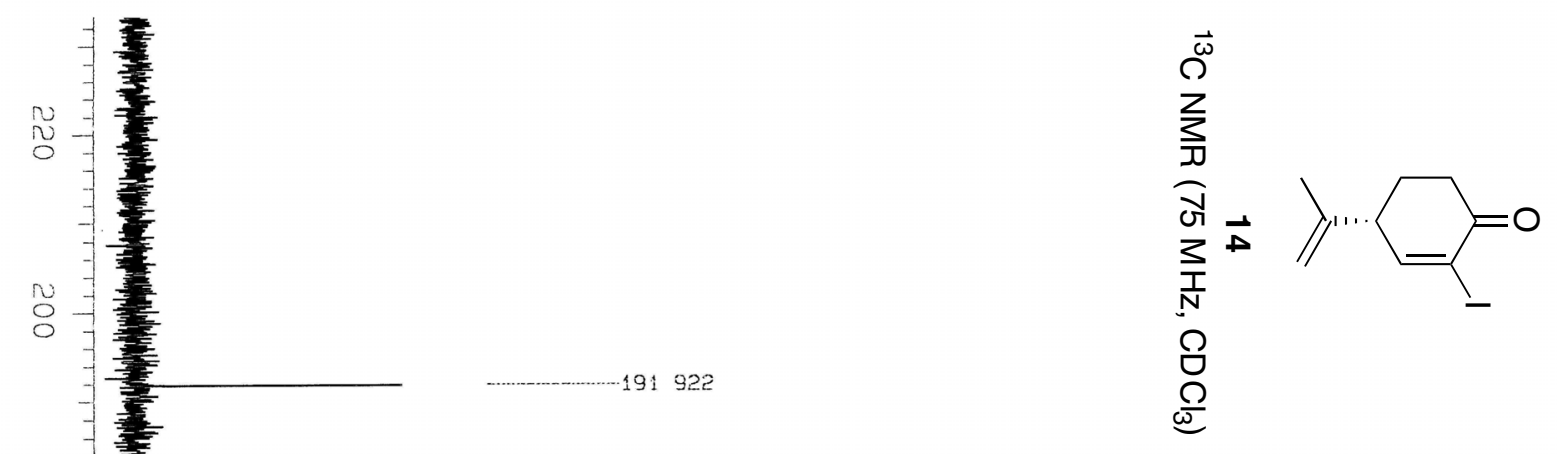

$\infty$

g)

oे

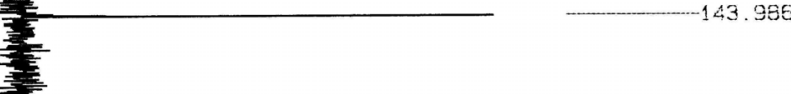

\&

毫
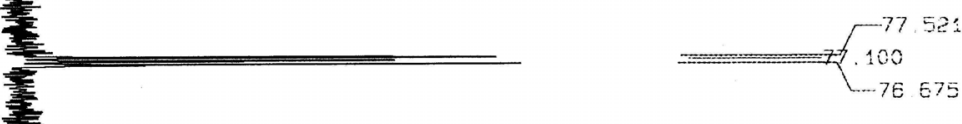

g)

o-

$\overrightarrow{8}$

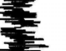

103.37

$-113227$

$6 \div .128$

으․
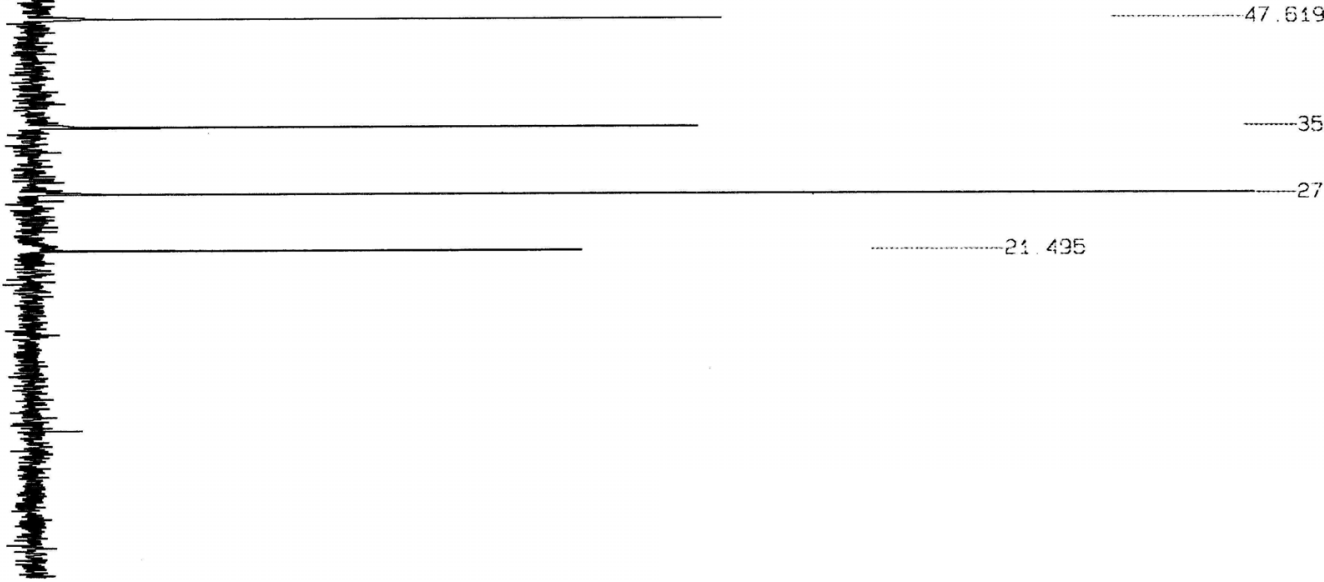

$-35.393$

27837

n

○

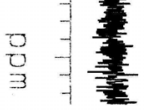




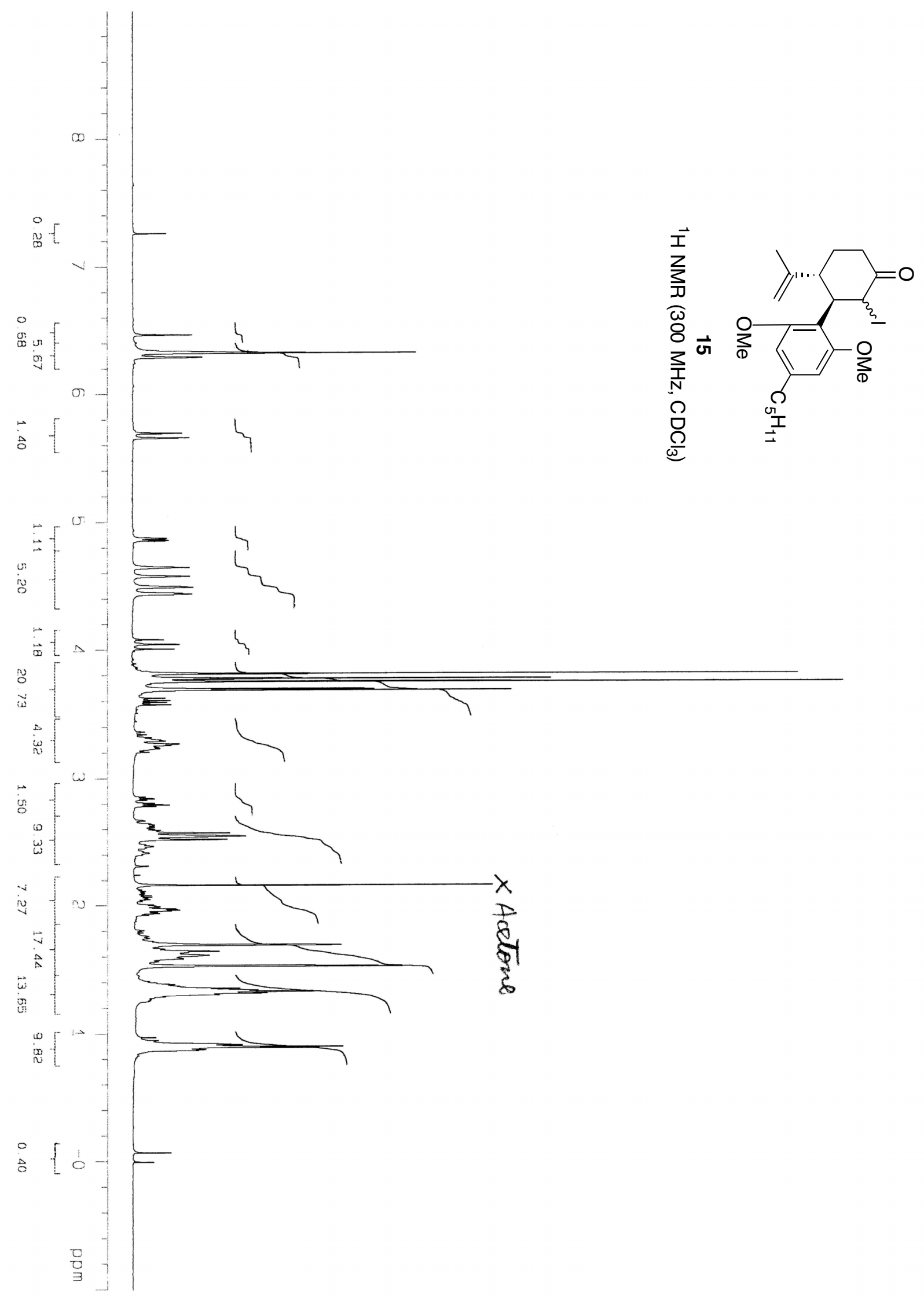

S-16 


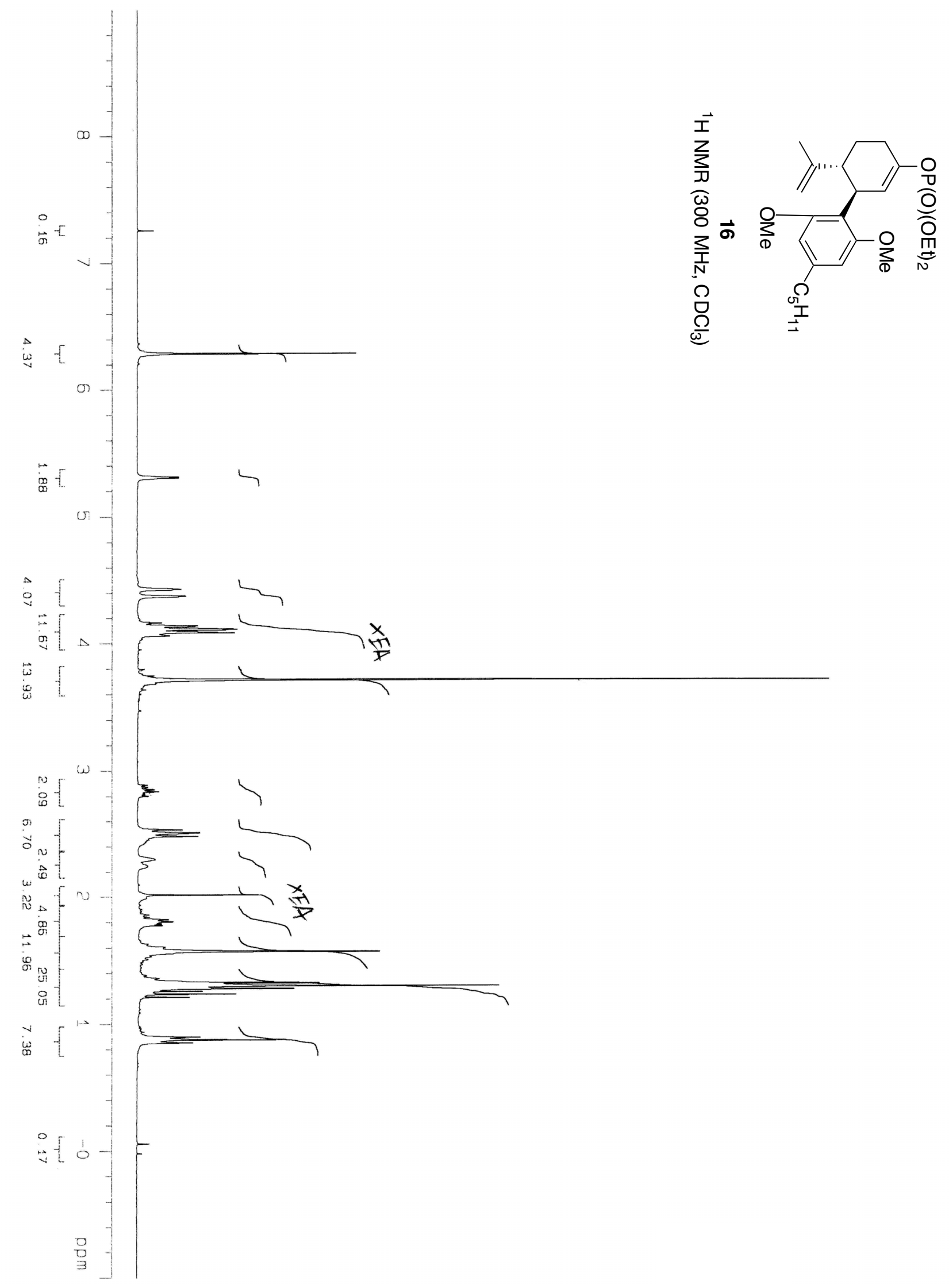




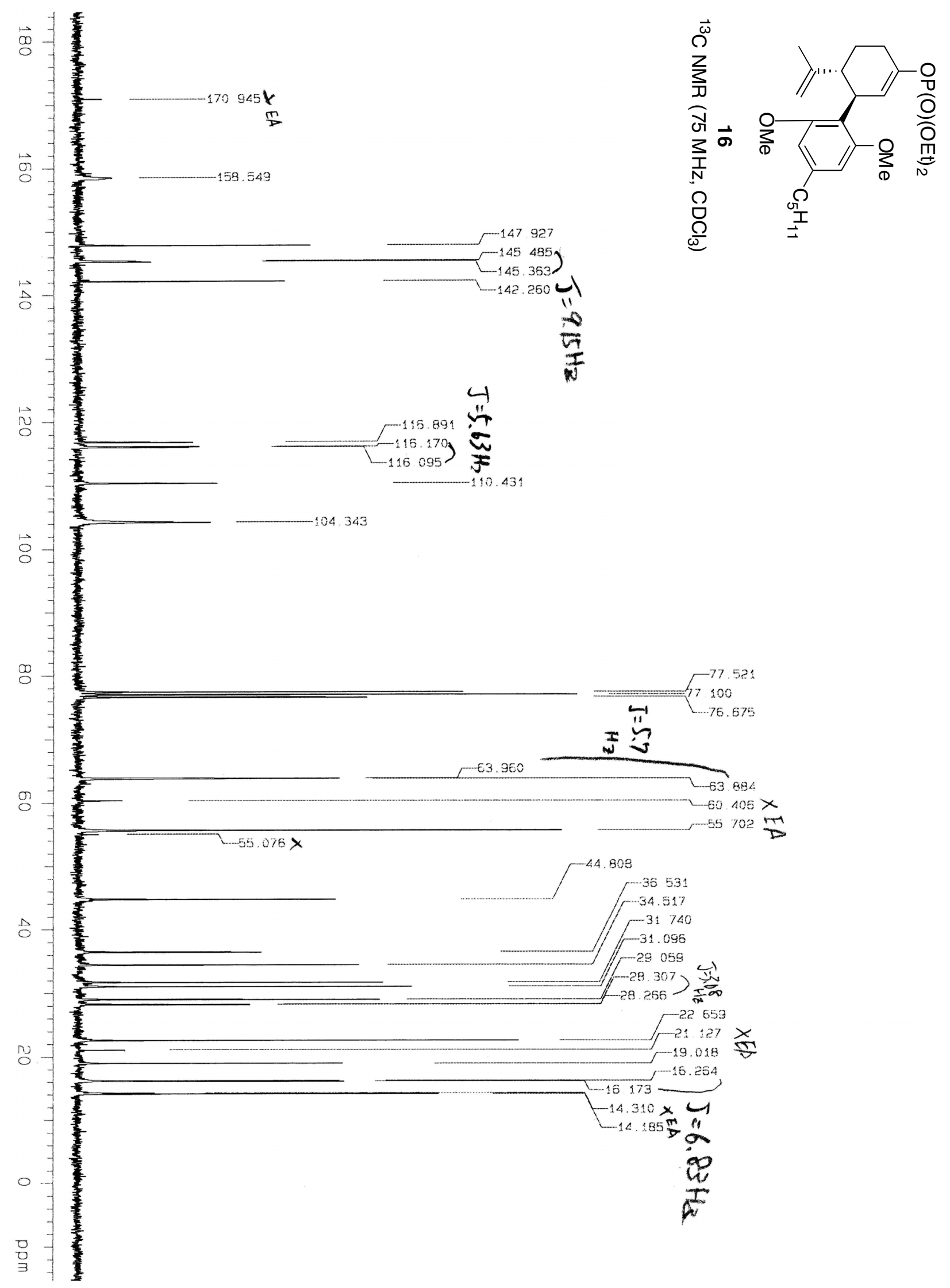




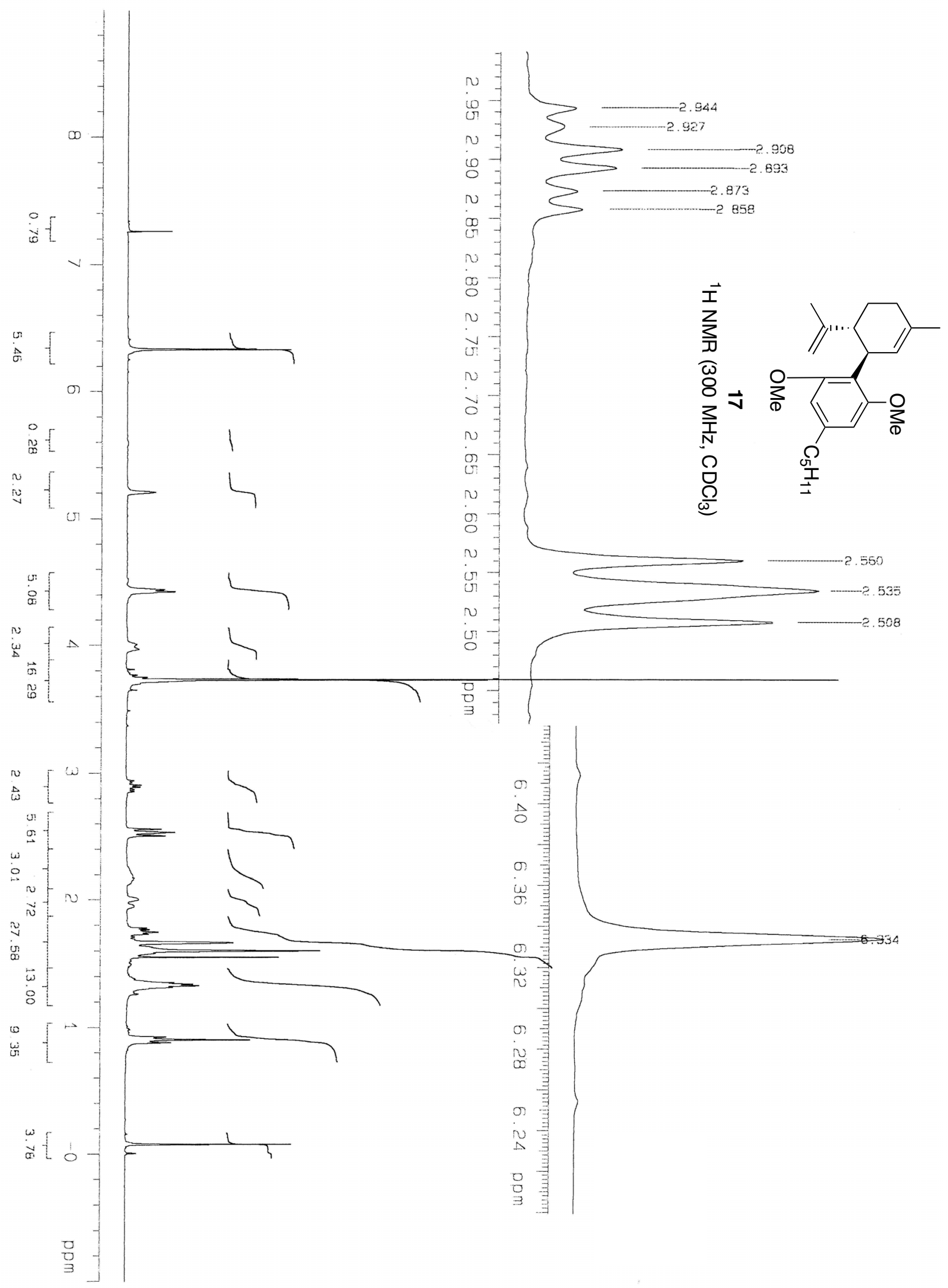




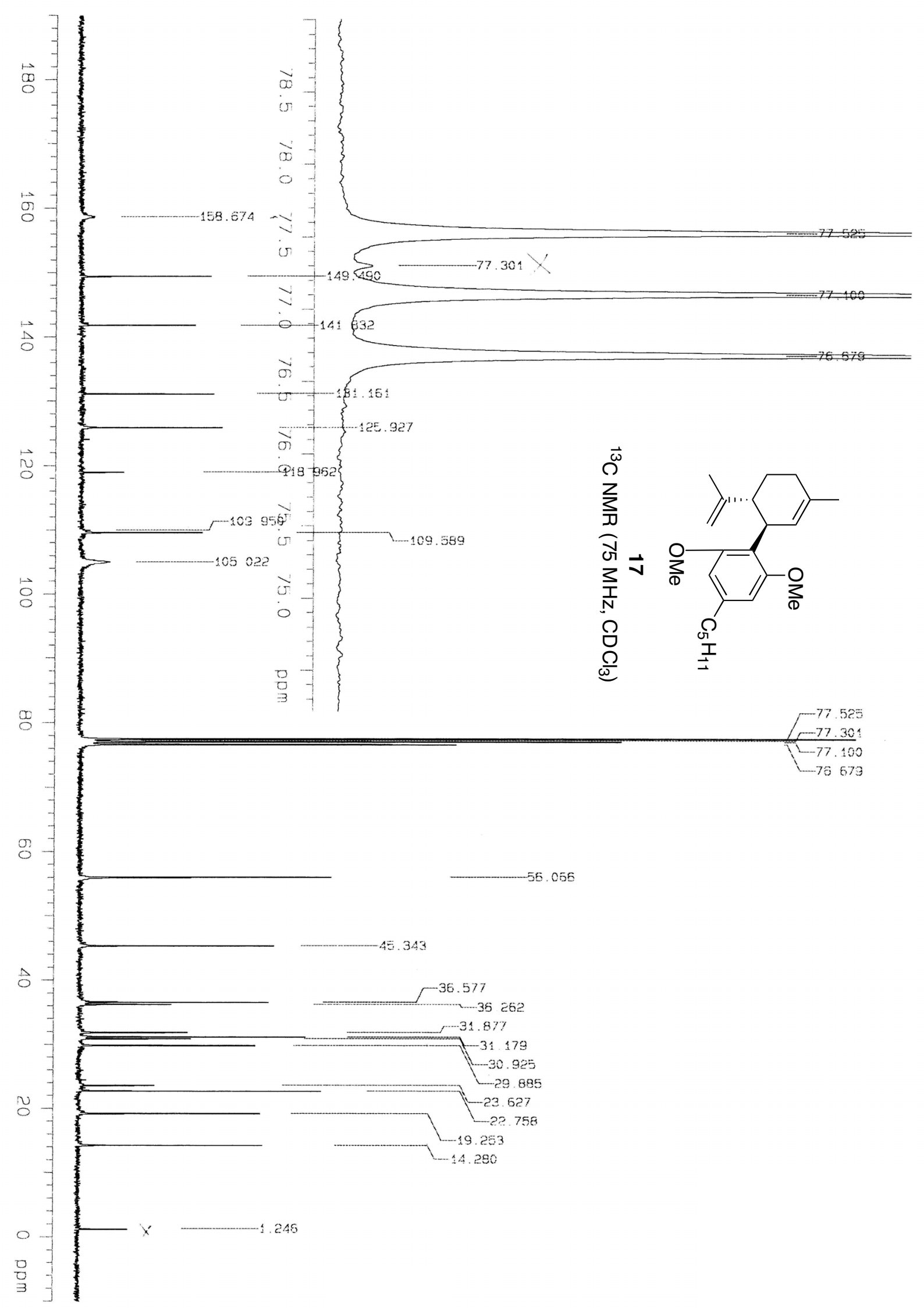

